\title{
CORRECTION
}

\section{Correction to: Electrochemical polishing versus mechanical polishing of AISI 304: surface and electrochemical study}

\author{
Ahmed M. Awad Abouelata ${ }^{1} \cdot$ Adel Attia $^{2} \cdot$ Gehan I. Youssef $^{2}$ \\ Published online: 25 October 2021
}

○) Springer-Verlag GmbH Germany, part of Springer Nature 2021

Correction to: Journal of Solid State Electrochemistry https://doi.org/10.1007/s10008-021-05037-2

The original article contained a mistake.

Equation 2, page 5, in the OV, the p-type should be corrected to $n$-type and the term $\mathrm{A} 2 / \mathrm{C} 2$ at the end of equation should be removed.

The original article has been corrected.

Publisher's Note Springer Nature remains neutral with regard to jurisdictional claims in published maps and institutional affiliations.

The original article can be found online at https://doi.org/10.1007/ s10008-021-05037-2.

\section{Adel Attia}

adel_attia@hotmail.com

1 Department of Chemical Engineering and Pilot Plant, Engineering Research Division, National Research Centre, Cairo 12622, Egypt

2 Electrochemistry and Corrosion Laboratory, Physical, Chemistry Department, National Research Centre, Cairo 12622, Egypt 